\title{
Constitutional Reform and Territorial Organisation in Italy
}

\author{
Giuseppe Bettoni 1,* \\ AQ1 \\ 1 Università di Roma "Tor Vergata", Rome, Italy \\ AQ2
}

\section{Abstract}

The abstract is published online only. If you did not include a short abstract for the online version when you submitted the manuscript, the first paragraph or the first 10 lines of the chapter will be displayed here. If possible, please provide us with an informative abstract.

Italy is experiencing a deep reform of its central state, after the reform of 2001 that was focused on the regional level. It has been a long process since 1992 and it is not finished. The antagonism between the central state and local levels (in particular the regional one) is the main characteristic in this country in the last 25 years and we cannot understand its evolution without an analysis of the power relationship between Italian political players. In this case the geopolitical methodology as defined by Yves Lacoste helps us understand the policy-making tools (especially at local level) and reforms used and to get a vision for the future.

In the last 20 years approximately, Italy has undergone profound administrative and political changes to its structure as well as to its Constitution. The changes have been numerous, but the general impression is that they are still incomplete.

Which raises the question: "what has changed, and in which direction"?

It is apparent that so far Italy has gone from a being a Republic divided into regions, yet still relying on a centralised structure (much like France), to a Regional or Federal State, resembling the Spanish and German models.

The result of the reform of Title V (Regions-Provinces-Municipalities) of the Italian Constitution of 2001 was a Republic based on principles radically different to those of the past. However, that reform was the product of a balance of powers that had the State at a disadvantage in comparison to the local communities, which resulted in much controversy. Consequently, the outcome of the 20156 reform witlould establish a new equilibrium of authorities.

In this article I first review the literature on territorial planning and relate its main ideas to some specific aspects of the Italian context. Then, I will detail the ongoing evolution of the Italian structure, in particular referring to the Action of the Public Actor and its impact on various parts of the country. This evolution is leaving some areas in Italy in an extremely difficult situation, especially when it comes to the administration of the territory.

Finally, the main focus of this article is to explain the concept of "administration of the territory".

Afterwards, I will study the constitutional changes and their most critical aspects.

\section{Decentralisation in Italy: Recent History and Motives}

The reasons behind the Italian institutional evolution from centralism to regionalism, only to try to return lately to a realignment in favour of the central state, are connected to two main motives: the changes in the 
power relationship between local government and central state, and an unsurmountable public debt that is currently rendering the financing of the Public Administration impossible.

These two points are actually connected, since the overwhelming debt has weakened the State to the point of being ineffective to the Regions. In the early 1990s, the Italian Republic had so much debt that supporting a political system based on clientelism within the Regions became unsustainable. Therefore the national politics lost validity in favour of local politics, which brought about the reform of Title $\mathrm{V}$ of the Constitution, as I will explain later.

This reform however was very imperfect, so much so that the relations between the State and local government became difficult and quarrelsome. The State ended up incapable to manage and organise public politics at any level on the whole territory.

This situation caused the launch under PM Renzi of a comprehensive constitutional reform which, while still a work in progress with no final documents yet available, in the long run has radically transformed one of the two branches of Parliament: the Senate. The people no longer elect their senators, instead the local governments choose amongst their own representatives to compose a 100-person Senate.

Aside from this very important change, a further adjustment affected the responsibilities that each institutional level had in the management of its territory. In fact, the first reform of 2001 gave equal jurisdiction to the State as well as to the Regions on the organisation of the national territory, national infrastructure included. This literally paralysed how the country shaped its main public politics. The current reform should instead make the Regions responsible to exclusively define their local public politics, not those which concern the Nation. In other words, the current reform seeks to rebalance the structure that came to life in 2001, and which was obviously favouring the local governments without preserving any coordination with the nation at large. For a deeper understanding of these processes, I should define my theory of Territorial Organisation, which refers to the French theory of aménagement $d u$ territoire.

\section{Aménager: To Organise the Territory}

I have chosen «organise» because it relates to the French term, which according to André Merlin is more appropriate to the context. He defines aménagement as: «l'action et la pratique (plutôt que la science, la technique ou l'art) de disposer avec ordre, à travers l'espace d'un pays et dans une vision perspective, les hommes et leurs activités, les équipements et les moyens de communication qu'ils peuvent utiliser, en prenant en compte les contraintes naturelles, humaines et économiques, voire stratégiques» ("The action and practice (instead of the science, the technique or the art) of arranging people and their activities as well as the infrastructures and means of communication they need, taking into account natural, the human and economic relationships, as well as strategic ones, in an orderly way in the space of a country and with the due perspective") (Merlin 2002). Pierre Merlin himself modified his definition a few years later in that he sought to achieve "order" to allow for "the functions and relations between people to be most agreeable, efficient and harmonious" (Merlin 2003).

Whereas Merlin's emphasises on the process of aménagement as the harmonious disposition and planning of the territory, Lacoste concentrates on tourism and geopolitics, establishing a new relationship altogether, by defining aménagement as: «action en principe volontaire et réfléchie d'une collectivité et surtout de ses dirigeants (et personne relativement influentes) visant à mieux répartir sur son territoire de nouvelles activités économiques et culturelles» ("A principally reasoned and voluntary action by a community, and above all its rulers (as well as relatively influential people), aimed at a better sharing of new economic and cultural activities on its territory") (Lacoste 2003 ).

Obviously this explanation is rather detailed, but it is worth highlighting how Lacoste perceives the role of the actors in planning the territory in his philosophy. Said role is often neglected or considered as an ancillary, almost unimportant aspect - which in turn has led geographers to pay little attention to it. We are too concerned with the possibilities to perform an objective assessment of the power and vision of the various actors. 
A professor, who is also a local elected official and a "planner" of the territory, gave us a much more direct definition of the way in which the political power plans its territory in a given society (Girardon 2006).

Carlo Salone reveals the critical aspects in Italy distinguishing the application of territorial policies as being divided in two distinct fields: economic programming, and urban and territorial planning (Salone 2005).

I will not analyse why Italy decided on an ill-considered separation of the territory and economic-political action. The reasons are probably to be found in the banning of the Italian geography (rightly or wrongly now is of little concern) since the end of the World War II. The ensuing spectacle is abundantly clear: a country that has evolved territorially in a profoundly disorderly fashion with all the associated economic, social, and environmental costs. This leads us to consider more holistically the concept of aménagement and above all the role played by this in tourism.

Francesca Governa studies the separation between politics and territory, where the latter is present merely as "passive support for action, affected by external processes" and is reduced to a "set of the favourite relations from the physical vicinity of the subjects" (Governa 2005). In her work she carefully examines the evolution of the role of territory above all in regard to elements such as governance. Let us consider here the alternative approach that Italian geographers have taken and its consequences in the so-called Territorial Planning policies. I prefer to define all the above as organisation, not merely for a linguistic quibble but to more closely capture the essence of the French word aménagement - which sums up all aspects of territorial planning, from building roads to choosing the perfect location for a child care centre. These two extremes, however far apart they may appear, do not simply belong to an engineer or a social worker, but derive from a public actor's will and vision, and from the territorial decisions he or she takes. As Merlin writes, the ultimate aim of territorial planning is to "sort out" a territory with the objective of producing "harmony", or, as Lacoste would say, the actor's "chosen vision".

Every form of territorial development is mainly concerned with these types of choices.

Any discussion of aménagement is wrought with complexity, not the least of which due to its various translations, especially when considering countless decisions which any territorial planner faces, and the transverse nature of all degrees thereof.

Evidently, every public action on a territory, which can be viewed as a process of intervention, is a political process based on forms of collaborative rationality (Subirats and Gallego 2002).

Healey concisely corroborates what has been said up to now against a vision overly bound to the architectonic "manufacture" or superfluously technical and aseptic. In particular, she researches the role of the planner defining him or her as "[...] an object of blame and hostility and the subject of our hopes for effective community regulation" (Healey 2006). Healey defines a "new communicative planning theory", in essence a more collaborative form of "planning", which is naturally desirable, yet immensely challenging to realise. What interests us more in her work is the refusal to divide of planning in sectors in favour of a "territorial" perspective which makes apparent how our activities interact with our way of life. If it is true that we have arrived at modernity through progressive stages such as public health and improvement of social classes, it is conversely true that we now face challenges such as the increase of economic inequalities and social exclusion.

Hence, "Territorial Planning" as simply planning or aménagement, as the organisation of the territory by the public actors is complex and multidisciplinary, and often gives rise to conflict (Bettoni 2009), and I will discuss how the 2001 constitutional reform in Italy was made not only in order to give more power to the Regions, but also in order to develop the national territory in ways distinct from the past. In some way this is the principle of "competition" between the territories. This "competition" has contributed, within the framework of the Italian reform, to an increase of inequalities between territories and, consequently, their residents. At this point it is crucial to recall three different and divergent types of territorial organisation: menaced, desired and rejected (Subra 2007). 
The menaced aménagement is what surfaces when companies shut down. This is a phenomenon widespread throughout a country like Italy, whose manufacturing base is largely comprised of low added-value production such as textiles or footwear. Today, almost all low value-added production has shifted outside of the EU. Whenever we encounter a relocation of a company to a developing country or one with low labour costs, the local residents of the territories concerned immediately protest, more or less violently. Other cases are exemplified by military bases (for example, in the north-east Regions such as Veneto and Friuli-VeneziaGiulia) or large state-owned industries going out of business.

The conflict concerning the desired aménagement centres precisely on the competition between territories. To make a particular territory attractive to foreign investors means to "tailor it" to the investors" needs, which requires specific interventions to the infrastructure. So, to render a territory attractive to investors in the biotechnology sector, we must think of intervening on what's considered to be critical in that sector. In this case, labour costs are not an important factor because researchers in a top-level pharmaceutical company are generally highly trained personnel. In fact, one of the key areas in this sector is located around Oxford and Cambridge, where labour costs are extremely high, but where the levels of training and research useful in this industry are just as high. Hence, territorial actors intervene to make their territory attractive; however, the competition is fierce within and without. The competition is also felt at the national level, where there is pressure to build infrastructure in one area, or to give preference to specific areas to launch profitable industry or economic development.

Lastly, rejected aménagement reflects the syndrome known as NIMBY (not in my backyard). In Italy there are many such cases (e.g. the gasification terminal in Brindisi and the high-speed rail line through Val di Susa). Namely, it concerns all those interventions which local residents oppose and obstruct, often aggressively (as lovingly documented by the Italian media) because they are sensitive to changes they consider threatening to their livelihood and their territory.

Subra's definition of the three types of aménagement is useful but not exhaustive in our view. In fact, it relates to implementing major infrastructure changes.

$\mathrm{AQ3}$

\section{Historical Changes and Redefinition of Constitutional Balances}

The conflicts being considered are, in fact, related to a certain type of public action that has an impact on the territory. Lacoste teaches us to analyse a territory considering all the others factors that can influence it (Lacoste 1994). For this reason the reform of Title V of the Italian Constitution should be considered as a redefinition of the issues in the planning of the Italian territories. This transformation has to be put into a precise historical perspective, beginning with the collapse of the Berlin Wall in 1989. In effect the disappearance of the world balance pertaining to the previous epoch also modified the Italian institutional structures. Therefore, all political parties that existed before 1989 completely lost their legitimacy, and in the course of a few years they all disappeared. The redefinition of the political equilibrium (also accompanied by the State's disastrous balance of payments) was such that the State failed even at its main function (Bettoni 2009).

AQ4

The Yom Kippur oil crisis led ruinously to the sudden increase of oil prices, therefore European countries had no choice but to adjust their budgets. Italy decided to continue with business as usual, which led in the course of the 1980s to an explosion in the national debt causing it to exceed $100 \%$ of the GDP (it is around $1352,7 \%$ inend of 2015).

In addition to this, the State became delegitimised in favour of local governments. In Europe this loss of legitimisation is bound up in part with the growing relevance of global events in daily life (even at the most "local" level), and in part to the influence of the European Commission, which is always ready to minimise national roles, and, to this end, it has repeatedly sought to support the role of the Regions. Globalisation has filled very many pages of the literature on the subject, and understandably so. The role of the State/Nation in the new context of fast Globalisation has not disappeared, yet has been considerably modified. The Regional actor (or Local, more generally) has not lost the opportunity to profit from this, and create a more important role for itself. 
In Italy this has occurred more strikingly than with our other European neighbours.

The reform of Title $\mathrm{V}$ of the Constitution transferred more important legislative power from the National Parliament (House of Representatives and the Senate) to the various Regional Assemblies. This is demonstrably the fundamental point of the reform.

The Constitution of 1946 referred to the Regions; however, they were not given any relevance until 1970, though even then their power amounted to very little. More than anything it allowed the growth of the local political class that strived to move up nationally. Very little institutional power to influence Public Policies was conceded to the Regions, so much so that most Italians did not know the name of their Regional president (just as often they did not know the name of their mayor).

The first changes were the direct elections of the Mayor (1993) and of the Regional Presidents (1995). Lastly the publication of the Testo Unico degli Enti Locali DL 267/2000 (Unified Local Authorities Law), which integrated the Law 265/1999, moved the reform forward substantially, but ultimately it did not complete it.

What should be underlined here is that the literature is unanimous in defining two Constitutional reforms, the one made by the Constitutional Law 1/1999, and the one by the Constitutional Law 3/2001; while they were incomplete, they brought profound changes to the functioning of the institutions of the Italian Republic.

Among the various changes, even before the new legislative and operating ones, each Region was supposed to receive enough power to control the electoral system, and to judge when the President and executive or council members would not be eligible or compatible. This power was assigned to the Regions to establish the internal Political system, leaving only to the State to establish the fundamental principles and duration of the elective offices. Moreover, the new Article 123 of the Constitution also disciplined the Council of Local Self-government "as a consultative body on relations between the Regions and local authorities", also allowing them to define the internal structure of the power relationships within the Region itself.

Amongst all this, Article 11 of the Constitutional Law 3/2001 alludes to a future reform of the Parliament (which was never made) to also integrate the work of the Local Authorities (Pizzetti 2007). However, up to date the fundamental role of Article 119 has not been activated.

If we look more closely at the reforms that were brought forward in 2001, Articles 117 and 119 give us an idea of the magnitude of this reform. However, this reform has not been completely applied, so the literature continuously discusses "reform of the reform".

The new Article 117 of the Constitution (substituted with Article 3 of the Constitutional Law of 2001) states that:

Legislative powers shall be vested in the State and the Regions in compliance with the Constitution and with the constraints imposed by EU legislation and international obligations.

The State has exclusive legislative powers in the following subject matters:

(a) the State's foreign policy and international relations; relations between the State and the European Union; right of asylum and legal status of non-EU citizens;

(b) immigration;

(c) relationships between the Republic and religious institutions;

(d) defence and armed forces; State security; armaments, ammunition and explosives;

(e) currency rates, sheltering of savings and financial markets; safeguarding competition; foreign exchange system; state taxation and accounting systems; evening out of financial resources; 
(f) State institutions and relevant electoral laws; state referenda; elections to the European Parliament;

(g) legal and administrative organisation of the State and of national public agencies;

(h) public safety and security, with the exception of local administrative police;

(i) citizenship, civil status and clerical offices;

(j) jurisdiction and procedural law; civil and criminal law; administrative judicial system;

(k) determination and guarantee of the basic level of benefits relating to civil and social entitlements;

(1) general provisions on education;

(m) social security;

(n) electoral legislation, governing bodies and basic functions of the Municipalities, Provinces and Metropolitan Cities;

(o) customs, protection of national borders and international disease control;

(p) weights and measures; standard time; statistical and computerised coordination of data of state, regional and local administrations; intellectual property;

(q) protection of the environment, the ecosystem and cultural heritage.

AQ5

While all this is fairly clear, what causes confusion is the vast extent of material defined in Competition between State and Regions.

More precisely the Article states:

- Concurringinternational and EU relations of the Regions; foreign trade; job protection and safety; legislation education, subject to the autonomy of educational institutions, with the exception of applies to vocational education and training; professions; scientific and technological research and the innovation support for productive sectors; health protection; nutrition; sports; disaster relief; following land-use planning; civil ports and airports; large transport and navigation networks; subject communications; national product, transport and distribution of energy; complementary and matters: supplementary social security; harmonisation of public accounts, and coordination of public finance and the taxation system; enhancement of cultural and environmental assets, including the promotion and organisation of cultural activities; savings banks, rural banks, regional credit institutions; regional land and agricultural credit institutions. In the subject matters covered by concurring legislation legislative powers are vested in the Regions, except for the determination of the fundamental principles, which are laid down in State legislation.

The Regions have legislative powers in all subject matters that are not expressly covered by State legislation.

At this point, the lack of a clear definition of roles - or worse still, such a broad list of cases whose jurisdiction is not clearly outlined - has led to a situation that many call "a variable geometry". Proof that this reform is ineffective is offered by the Constitutional Court. Before the Reform of 2001, the Constitutional Court cases concerning the State and Regions were $20 \%$ of the caseload. Today that caseload has increased to over $50 \%$. Consequently, the Constitutional Court has acquired the new role of administrating the Italian institutional life at its various levels. This is one of the main points that the Renzi 
Reform is trying to adjust and, if the approval date is unknown, it seems quite obvious that the concept of concurring legislation has disappeared from the Italian Constitution.

Article 119 of the Constitution confirms: "Municipalities, provinces, metropolitan cities and regions shall have revenue and expenditure autonomy. Municipalities, provinces, metropolitan cities and regions shall have independent financial resources. They set and levy taxes and collect revenues of their own, in compliance with the Constitution and according to the principles of coordination of State finances and the tax system".

Obviously, as this was never enacted, the Regions' activities are not only indeterminate in regard to Article 117 , but they are also insecure, given the lack of a viable financial funding system.

However, the Regions have experienced an increase in their duties, such as providing for Public Health. As a result, the Regions' powers of action have been practically "blocked" since the Health refund represents a large part of their operative budget.

In situations such as Lazio and also Calabria, the weight of Public Health expenses and responsibilities on the budget is such that any other action becomes impracticable. Other Regions have better outcomes, but still endure great difficulties.

The Italian context after this important yet incomplete reform, beyond the purely technical aspects which create major problems, brought the concept of citizenship into question, as a consequence of missing essential definitions of citizenship. Each citizen has assorted interests according to the multiple existing institutional levels. For example, a regasification terminal is important for the nation as a whole because it increases the competition between the natural gas suppliers, including countries that are not directly connected to us by pipelines, and therefore reduces the cost of gas for everyone. Yet at the same time my interests as a citizen are directly affected if this regasification plant is constructed in or near my place of residence, because of acoustic, olfactory, and visual nuisances, and possible health hazards. Ultimately, what is the dominant interest between the different levels that concern the citizen? The local, the Regional or the national? The German Constitution, for instance, points to the national interest as the dominant one, even though the strongest power is awarded to the Regions. In Italy the conflict of interests remains unresolved. Calling Germany into question is important because the Renzi Reform applies a similar "national interest" concept, as I will explain later.

This example of programming policy easily demonstrates a concrete aspect of the Italian public policies with all their difficulties and confusions. As I mentioned earlier, the unsustainability of the early 1990s budget called into question the criteria of Public action at all levels, as well as a radical change of the development policies. It was in this context that the New Programming Policy was enacted.

\section{Towards the "New Regional Policy"}

During the post-war reconstruction period, the programming policy was mainly based on the intervention of the state as "controller" of the economy. At that time, "programming" simply concerned the actions taken by the various public authorities through negotiations with the private actors.

The "territories" weren't considered at all at this time. Nobody considered the various territorial peculiarities which could have imposed specific political interventions: the best scenarios concerned targeted interventions; in other cases the interventions simply consisted of a series of scattered distribution of resources and financing. These political programming efforts applied national intervention policies without differentiating among the areas where the intervention was made. The levels of growth were so rapid that the successful interventions in some areas overshadowed the financial squandering and local hardships present in other areas. At this time, studying the territory was considered a waste of time, much like the knowledge and understanding of the various local networks; the omniscient Italian "centre" knew all, and planned the interventions based on that. The centralism of the Italian government was different from that of France, where the centre administered and programmed every territory of the State in complete autonomy. In Italy, the centre "programmed" under pressure by local actors, but in the absence of complete information about the local situations, therefore in the absence of a balance of power. In short, the strong local actors who were 
able to negotiation with the centre did so chaotically, and at the expense of the other less vocal local actors. The result of such display of imbalance was that the centre only came to know the strategies of the dominant local actor, and consequently subsidies, various concessions and derogations from the master plan, etc. proliferated considerably_which is what Barca calls "Negotiation without programming" (Barca 2006: 72).

Italy's turning point can be seen in two important decisions: the first was the closing of the agency that protected the interest of the Southern Italian regions, also known as the Mezzogiorno Agency; the second was prohibiting the state from covering the deficits of companies. While the fast growth of the first thirty years of the post-war period had already faded, these two factors imposed a severe evaluation of the expenditures, a more coherent and transparent management of the public intervention and, above all, a thorough assessment of the financial resources. A true cultural revolution began in 1992, which coincided with the "mani pulite" scandal, which shed light on financing of local and national politics based on patronage and corruption, and which broke down the Italian political system. This also led to the modification of the language used in the Public Administration, which, in turn, generated various assessment methods of investments, policies, and administrative activities. Slowly, principles such as governance, which up to then had only been theoretical, started to appear in the everyday activities of the public actor, and gave rise to projects which were no longer requested after negotiation with the most powerful territorial actor, but which involved the authentic participation of various public actors at different levels, and of interested private actors (the most relevant example of recent years of this is the Territorial Pacts).

In addition to these events, the European Union forced Italy to modify its interventions for the development of the Italian Mezzogiorno, which had been largely unsuccessful, and which generated new initiatives, which Barca calls "integrated collective services" (Barca 2006: 74).

In the attempt to create a government of multilevel interventions with the authority to address and concentrate its competencies, the cities and municipalities on the one hand propose these projects which the region has then to select and approve; on the other hand, the Modernization of the Public Administration System, thanks to a system of rewarding by increasing financing for any similar initiatives, puts into practise and circulates a culture of "assessment".

All of the above is concerned with increasing the so-called "social capital". This change was tricky in that it could create expectations in the private actors, who conceivably would increase capital investment. However, the implementation of the new Regional policy did not have the outcomes the Department for Development and Cohesion Policies hoped for, which were the development of new ideas with subsequent investment opportunities and a growth cycle. Indeed, Barca himself did not hesitate to admit that he was expecting a rate of growth for the Italian Mezzogiorno which could double the average rate of growth of the member countries of the European Union.

The most relevant result achieved in the Regional policy of Southern Italy shows a decisive turning point for the institutional functions of the State, and its relationship with both public and private actors. Obviously there is a series of consequences related to these changes, such as the new need of "transparency" and "simplification" of bureaucracy, even of the notoriously thorny administrative language. Even in view of the meaningful results achieved in Southern Italy regional policies, there were also several half-done projects' outright failures.

Surely, one "partial success" is the positive level of growth although it did not meet expectations. A serious international crisis can't be considered as the only factor for the unmet growth expectations in Southern Italy. Many scholars, including Barca (Barca 2006: 94), believe that this problem depends not only the inadequate budget for capital expenditures proportionate to the expected goals (Rossi 2005), but also on the slowdown effect that public perception of slow growth has created worldwide.

Barca shifted the attention on Education and Research, on the appreciation and endorsement of natural and cultural resources, of local products, and of tourism. However, one of the main reasons for the failure resides in the previous division in various sectors, which was never compatible with a political intervention which, in turn, should have contemplated a territorial division. 
On the other hand, the new Regional Policy did introduce positive institutional changes. In the early 1990s, a proper programming policy such as a Regional Development Plan did not yet exist for the various authorities in southern Italy. Everything that was supposed to be "policy" was just "filed away somewhere in a desk drawer". The underlying problem was that the policy did nothing to strengthen the authorities and change the status quo. Moreover, there was no formal assessment of responsibilities, control, and use of financial resources. With a few exceptions, anarchy reigned. Worse yet, the cooperation between the State and the Authorities, where all communication flowed on a direct channel between these two levels, was less than satisfactory for both, and drove choices that we could define as "paternalistic" at best, which discouraged external participation, particularly from the private sector. The old policy, which made sure that the State could receive reports on allocated resources, though actually never verifying that resources were used properly, was abandoned in favour of the new Regional Policy. Today, the different governmental levels in collaboration with social actors establish the priorities for the use of resources; these funds, or "conditional grants" will be given to the responsible authorities that will employ them in accordance with the regulations and the expected goals. The only disadvantage in this model, which is inarguably better than the past scenario, is that it does not take into consideration the territorial diversification. In fact, Barca writes that, while the grant always describes which services, incentives, and type of project among the priorities and the addresses, only a few times it says "where" to allocate the funds (Barca 2006: 80).

\section{Public Administration Operation and Financing}

The Renzi Reform does have repercussions on the administrative structure, especially on human resources and their financing.

One must remember that that all public financing was subject to reforms as Italy spent its last semester as UE President, with Law 196 of 31 December 2009, which experts considered viable, and which led the way to Law 29 of 7 April 2011.

AQ6

The originality of these reforms is due to UE reforms that were implemented after the worldwide economic crisis of 2008 and 2009, which has shed light on how many European countries mishandled public financing. AQ7

Regardless of the two legislative interventions I mentioned, the public accounting and financing has yet to function smoothly in many ways.

Underlying the new layout of the financial relationships between State and local government is the elimination of derivative financing, and greater autonomy for the Regions and local governments to receive and allocate money in line with principles of solidarity and social cohesion.

Therefore, policies have moved away from a system of transfers based on historical spending towards one of allocation of resources based on the identification of basic needs which guarantee total financing of the essential civil and social rights as well as of the basic functions of the local governments.

69/2011 is the main legislative decree for the implementation of Law 42/2009. The text is composed by 48 articles organised in 5 chapters. Chapter I establishes the rules on the Regions' tax system, and determines that, after 2013, the Regions' additional contribution to IRPEF (which is the Italian income tax) must be recalculated, and the IRPEF rates reduced so that the Regions can have income that is equivalent to the elimination of the transfers from the State.

The other Chapters which compose the decree study the contributions from and to the provinces; the equalising fund for the local government, and the financial system of metropolitan cities (Chapter III); the costs and standard needs for the Regions' public health expenses (Chapter IV). Chapter V, finally, makes provisions for the permanent Conference for the coordination of public financing, whereas Chapter VI describes final norms and revocations. 
The Additional IRPEF, that is, a percentage of the income tax rate that the Italian people pay to the State, is the Regions' main income. The State determines the income tax but the Regions can increase it up to a maximum of $2.1 \%$ in 2015 . Other contributions to the Regions would be added to this in the future.

The Regions also will profit from the revenue gained from the battle against tax evasion and illegal real estate development.

The "standard need" is a fundamental concept in the elimination of the State transfers based on historical spending. Once the public agencies inside services such Public Health, Education, Transportation define the Essential Benefit Levels (Livelli Essenziali delle Prestazioni or LEP), the State will schedule transfers to match the Standard Costs, as mandated by Law 42/2009.

Historical spending indicates what the history of expenses has been for a specific service. In the past this criterion determined the State transfers to the various Regions based on what one Region had spent the previous year.

Standard costs indicate the cost of a specific service given in the best conditions of efficiency and appropriateness, and consistent with the essential benefit levels. This cost is calculated by taking the most "virtuous" Region which offers services at the "most efficient" fees. Essentially, to finance the local governments the cost must be determined in accord with an efficient and effective Public Administration management, keeping in mind the ratio between the number of employees in the local government and the number of residents.

The standard costs represent the new economic model on which to ground the total financing of the public services that afford citizens the core social rights of health, social work, education, as well as local public transport. Essential benefits and public services will be introduced in this "retributive" system in relation to the average needs to be satisfied. These needs or requirements are identified to guarantee that services and benefits are provided nationally in conditions of efficiency and appropriateness.

Public Administration personnel in Italy follows these characteristics:

- access through national examinations;

- the public nature of the authority;

- the correlation with the institutional scope of the public authority;

- subordination with job placement in the public authority's administration;

- continuity (temporary contracts included);

- exclusivity;

- predetermined salaries.

All Italian public employees nowadays are no longer employees of public law but of private law, specifically regulated by the legislative decree $165 / 2001$, which is the normative text for the discipline of public offices and work in public administrations. The exceptions are the following employees:

- full, administrative and accounting magistrates;

- State and district attorneys;

- military personnel and police;

- Fire-fighters; 
- diplomats and prefects;

- employees of the Banca d'Italia, of Consob (the National Commission for the Enterprises and the Stock Exchange) and of the Authorities that guarantee fair competition and markets;

- the employees of independent authorities;

- university faculty.

The rearrangement in management is crucial for the reform, and gives managers the so-called "unique role", one for the State, one for the Regions, and one for the local governments. The managers' appointments are assigned on merits and professional development, and can last up to four years, which then may be extended by a one-time appointment for two additional years. Those who lose the appointment may petition for a demotion to clerk and keep their place. In any case, retrenchment is tied to a negative evaluation. An appointment can be removed or revoked in sectors that are particularly exposed to corruption for those managers who have been indicted even though still awaiting judgment by the Court to pay restitution. The City Secretary position was removed.

In conclusion, between changes in financing and personnel management, we can see how costs have been reduced and the power relationships between State and local governments have been rebalanced, just as we outlined at the beginning of this essay.

\section{Advantages and Disadvantages: Towards a Geopolitical View?}

The last decade has been witness to regional policies which are positive and relevant, although many of them still raise doubts in the experts. The DPS finds at least ten main points for consideration; however, my aim is to address only the most important. First of all, thanks to this new method, the regional policy has become more "programmable" and easily "monitored". The local administration and its dominant culture have improved effectiveness and efficiency, although these changes cannot be easily quantified or measured. Moreover a sort of unification of the national regional policy has begun, by the same standards as the European regional policy, which has made way for an "under-utilised area fund". This unique fund responds to the same European regulations at least for allocating resources, and selecting and monitoring projects. It is well known that the European regional policy made innovations in rationalisation, transparency, and monitoring, but it is also true that for well-known historical reasons, the policy turned a blind eye towards the field of territorial selection.

These are the same reasons that imposed the signing of a unique but damaging treaty, where it was not possible referring to territorial cohesion, but only to social and economic cohesion (Bettoni 2004). The choice of the sectorial characteristics, which allow access to the communitarian resource, depends on sector variables, such as a particular area exhibiting economic decline and a specific unemployment rate for several years, whether or not it is an industrial or agricultural area. This strict regulation does not consider all the characteristics of each territory, and even less so, the peculiarities of the social networks which can invite either success or failure. The true reasons of this territorial "blindness" are not related to scientific objectivity (as many believed at the time), but rather to the fact that the member countries have never allowed the European Commission to be vocal about the territorial decisions taken in the various countries. It is no coincidence that the Unique Treaty mentions only the Social and Economic cohesion (exception made for the section on the general-interest services, where the "territorial" variable appears for the first time), while the European Spatial Development Perspective talks about Territorial Cohesion (in fact this last document is not as coercive as the Unique Treaty) (Husson 2002). This strategy is not without its problems, such as on the one hand the excellent results of the Agricultural Policy of France; on the other hand, both social and economic catastrophes in Portugal. So I ask: "Why apply characteristics to the national Regional Policy that belong to the European policy?" Keep in mind that these characteristics are independent from territorial discrimination. 
The Framework Agreements, which generated a more direct coordination of difficult situations, were another positive addition in the new Regional Policy; so later on a concentration of interventions helped to avoid the fragmentation that had been an obstacle for optimisation and rationalisation. Lastly, the new tools known as the "Territorial Pacts" and the "Integrated Territorial Projects" led to the highest level of integration among the various territorial-actors policies.

At this point, in keeping with the Internal Geopolitics approach, I should discuss the merits of the Pacts or of the various projects which have prompted different actors to plan a collaborative intervention. At first, these projects were considered as economic decisions only and did not account for the diversity and the antagonism of each actor's different view. This approach has also influenced the evaluation of the various projects, which, if objective, would avoid all the incoherent programming policy and inefficient interventions. However, this search for objectivity has underestimated, and at times not weighted at all, certain essential variables which could void the whole method of valuation and programming. Barca underlines the inadequate cooperation among the various administrations, and what an obstacle this was for the expected achievements of the new Regional policy: Barca's "[...] sectorial policies incoherent with the regional policy [...] in the territorial integration of national interventions" (Barca 2006) relate to the failure to establish a "centre" as a highly competent place, a reference point which could regulate and address policies. This is arguably the most important point for the power of local actors, particularly regional ones, who find the tools they are given by the European Union and the Central Government, but they are given no regulations that would increase cohesion and collaboration horizontally. The limitations of this practice highlight the internal geopolitics at play, especially the antagonism among territorial actors which wish to control the evolution of the territory.

\section{A New Reform: The National Interest Before the Local Interest}

The idea of a new reform after 2001 was clearly outlined by political scientists, as proven by a barrage of Constitutional Court materials. However, this reform was incomplete and the product of power relationship on behalf of regional level.

At the beginning of 1990s, the Central State was delegitimised by decades of bad management exemplified by one of the heaviest public debt amongst European countries, and by a colossal scandal of corruption of its Parliament. The reform of 2001 produced a confused Constitutional structure that created disparities on the national territory as a whole. The management of public actors without a clear national vision (Art.114 of Constitutional law), and too many competitors between Regions and Central Government (Art.117 of Constitutional law) generated only chaos and turmoil. The Constitution of 2001 gave the Regional Governments total freedom to initiate their own policies without a national reference: the Regions had the opportunity to refuse a national infrastructure on their territory, but the Central Government cannot reject a local project (except in specific matters) if it placed the national interest at a disadvantage. The Renzi Government tried to fit that in the new Constitutional Law (Article 117 (3)).

The timing of this reform is also quite important. If during the 1990s the nation was in a position of weakness because of the corruption and the heavy public debt, in the last ten years the most powerful Regional Governments have shown their shortcomings and some failures that put them this time under the spotlight (the case of "Mose" in Venice, and the Expo in Milan and Lombardy are just the most famous cases of corruption and embezzlement, but also regions like Emilia Romagna, Tuscany, Piedmont and Lazio have had their own).

The reason for a new Constitutional reform is to establish a new balance among the Italian political actors, and it is essentially a redefinition of power on behalf of the State. These are the main points:

1. The Senate became a Chamber of local entities and its members are chosen among members of Regional Councils (74) and Mayors (21): the members will be nominated directly by each Regional Council.

2. The provinces are no longer a level of Government directly elected by People.

3. The jurisdiction of States and Regions is clearly indicated in the Constitution: the concurring 
legislation disappears.

4. The national interest for citizens is clearly indicated as the main principle behind the reform.

5. The Regions' legislative power is limited to the regional interest. For example a Region cannot act on an infrastructure that concerns the national interest.

\section{Conclusions}

The Italian situation is critical and the strong and lively debate during the reform process in 2016 proves it.

First of all, without this reform, in the short-to-medium term, the territory may not become competitive enough either for the country's productivity or to attract other investors. The great confusion at the local level makes it very difficult to plan serious investments for any sort of productive activity. This is an acute problem that pushed the Renzi's Government to this reform. Moreover, no shared national document exists which clarifies what development plan is in place for the various parts of the country. There are many specific documents, but none of them tells us what should be the common vision for the South-East of Italy, for example (or a national plan attempting to put together a Mediterranean "system"). In other words, no system of integration of the Northern and Southern portions of the Sea is in place. How can local actors decide their policies if they do not know what the overall plan for the country will be? This point is still not resolved in the Renzi reform (this reform must to be aproved by a popular referendum on December 4th 2016).

The greatest risk is the total absence of national cohesion. If a community no longer has an authentic common core of solidarity and a shared view of the direction it should take, there is no longer a reason for the "nation" to exist. Can we consider Italy as a nation whose existence is in danger? It is hard to say, but certainly the ingredients for such a crisis are all present. And yet, it will not come to such a dramatic scenario, we hope, for it is much more probable that Italy is unable to confront the competition in the markets and will stabilise in the steady decline that we have witnessed over the recent years.

\section{Bibliography}

Barca, F. (2006). Italia Frenata. Rome: Donzelli editor.

Bettoni, G. (2012). Geografia e Geopolitica Interna. Dall'organizzazione territoriale alla sindrome di NIMBY. Rome: Franco Angeli.

Bettoni, G. (2009). Dalla Geografia alla geopolitica. Milan: Franco Angeli.

Bettoni, G. (2004). Il Territorio italiano oltre il federalismo, in Bollettino della società geografica italiana, $\mathrm{n}$. 3 Luglio-settembre 2004, Roma, Serie XII, vol. IX (2004), pp. 617-632.

Girardon, J. (2006). Politiques d'aménagement du territoire. Paris: Ellipses.

Governa, F. (2005, May-August). Territory and collective action in the policies of local development. Geotema, n. 26, Year IX, 49-66.

Healey, P. (2006). Collaborative planning: Shaping places in fragmented societies. Basingstoke\New York: Palgrave Macmillan.

Husson, C. (2002). L'Europe sans Territoire. Paris: L'Aube/DATAR.

Lacoste, Y. (1994). Dictionnaire de Géopolitique. (Préambule). Paris: Flammarion. 
Lacoste, Y. (2003). De la Géopolitique aux paysages, dictionnaire de la géographie, entry «Aménagement». Paris: Armand Colin.

Merlin, P. (2002). L'aménagement du territoire. Paris: PUF.

Merlin, P. (2003). Aménagement du territoire. In P. Merlin \& F. Choay (a cura di) Dictionnaire de l'urbanisme et de l'aménagement (pp. 38-43). Paris: PUF.

Pizzetti, F. (2007). Piccoli comuni e grandi compiti: la specificità italiana di fronte ai bisogni delle società mature. Astrid-online http://www.astrid-online.it/--le-trasf/Studi--ric/FRANCOPIZZETTI-piccolicomuni.pdf

Rossi, N. (2005). Mediterraneo del Nord. Un'altra idea del Mezzogiorno. Rome-Bari: Laterza.

Salone, C. (2005). Territorial policies: Collective action within the territorial dimension. Turin: UTET.

Subirats, J., \& Gallego, R. (2002). Veinte anos de autonomias en Espana. Leyes, politicas publica, instituciones y opinion publica. Madrid: CIS.

Subra, P. (2007). Géopolitique de l'aménagement du territoire. Paris: Armand Colin. 